\title{
Effects of age on histological parameters of the sweat glands of Nellore cattle
}

\author{
Mara Regina Bueno de Mattos Nascimento*1, Enéias Aurélio Dias ${ }^{2}$, Thaisa Reis dos Santos ${ }^{3}$, \\ Gustavo Ferreira Ayres ${ }^{4}$, Carolina Cardoso Nagib Nascimento ${ }^{4}$, Marcelo Emílio Beletti ${ }^{5}$
}

http://dx.doi.org/10.1590/0034-737X201562020001

\begin{abstract}
Effects of age on histological parameters of the sweat glands of Nellore cattle

The sweat glands are important in thermoregulation of cattle in a warm environment as they help dissipate heat through evaporation. Studies on gland histology are important to define its secretion potential and the capacity of perspiration and heat removal. The objective of this study was to determine, by histomorphometry, glandular epithelium height, the depth of the gland, length of the glandular portion and number of glands per $\mathrm{cm}^{2}$ of the sweat glands of the three age groups of Nellore cattle. Thirty females were used in this study. They were equally divided into calves, heifers and cows. Histological sections were obtained and analyzed by digital images in Trinocular BX40 Olympus microscope coupled to an Oly - 200 camera, connected to a computer. The images were obtained with microscope with $2 \mathrm{x}, 4 \mathrm{x}, 10 \mathrm{x}$ and 40x magnification objectives. The measurements were performed using HL Image 97 program. The height of glandular epithelium, depth of the glands, length and density of the glandular portion per $\mathrm{cm}^{2}$, were all analyzed. The calves showed greater height of the glandular epithelium than heifers $(\mathrm{P}=$ 0.0024), and cows $(\mathrm{P}=0.0191)$. The depth of the gland was not influenced by age. Cows had higher length of secretory portion than heifers $(\mathrm{P}=0.0379)$ and calves $(\mathrm{P}=0.0077)$. Heifers had a greater number of sweat glands per $\mathrm{cm}^{2}$ of skin than cows $(\mathrm{P}=0.023)$. In cattle, the height of glandular epithelium and the density decreases as animals get older. On the other hand, the length of the secretor portion increases but with no changes in the depth of the sweat glands.
\end{abstract}

Key-words: Bos indicus, glandular epithelium, histomorphometry, microscopy, sweat gland.

\section{RESUMO}

\section{Efeitos da idade sobre parâmetros histológicos das glândulas sudoríparas de bovinos da raça Nelore}

As glândulas sudoríparas são importantes na termorregulação dos bovinos em ambiente quente, uma vez que auxiliam na dissipação de calor por evaporação. O estudo da histologia da glândula é importante para definir seu potencial de secreção e, consequentemente, a capacidade de sudação e eliminação de calor. Neste estudo, objetivouse determinar por histomorfometria a altura do epitélio glandular, a profundidade da glândula, o comprimento da porção glandular e o número de glândulas sudoríparas por $\mathrm{cm}^{2}$ de três faixas etárias de bovinos da raça Nelore. Foram utilizadas 30 fêmeas, divididas igualmente, em bezerras, novilhas e vacas. Os cortes histológicos foram obtidos e analisados por imagens digitalizadas, no microscópio Olympus Triocular BX40, acoplado a câmera Oly-

Submetido em 02/10/2012 e aprovado em 24/03/2015.

'Universidade Federal de Uberlândia, Faculdade de Medicina Veterinária, Uberlândia, Minas Gerais, Brasil. maran@umuarama.ufu.br ${ }^{2}$ Agência Goiânia de defesa Agropecuária - AGRODEFESA, Goiânia, Goiás, Brasil. eneiasaurelio@ yahoo.com.br

${ }^{3}$ Universidade Federal de Uberlândia, Faculdade de Medicina Veterinária, Uberlândia, Minas Gerais, Brasil. thaisa_vetufu@ yahoo.com.br

${ }^{4}$ Universidade Federal de Uberlândia, Faculdade de Medicina Veterinária, Uberlândia, Minas Gerais, Brasil. carolnagib@yahoo.com.br

${ }^{5}$ Universidade Federal de Uberlândia, Instituto de Ciências Biomédicas, Uberlândia, Minas Gerais, Brasil. mebeletti@ufu.br

*Autora para correspondência: maran@umuarama.ufu.br 
200, ligados a um computador. As imagens foram obtidas com microscópio em objetivas de 2x, 4x, 10x e 40x. As mensurações foram realizadas pelo programa HL Image 97. Analisaram-se a altura do epitélio glandular, a profundidade da glândula, o comprimento da porção glandular e a densidade por $\mathrm{cm}^{2}$. Bezerras apresentaram maior altura do epitélio glandular que novilhas $(\mathrm{P}=0,0024)$, e vacas $(\mathrm{P}=0,0191)$. A profundidade da glândula não foi influenciada pela idade. Vacas apresentaram maior comprimento da porção secretora que novilhas $(\mathrm{P}=0,0379)$ e bezerras $(\mathrm{P}=$ 0,0077). Novilhas apresentaram maior número de glândulas sudoríparas por $\mathrm{cm}^{2}$ de pele que vacas $(\mathrm{P}=0,023)$. Nos bovinos, o aumento da idade reduz a altura do epitélio glandular, aumenta o comprimento da porção secretora e diminui a densidade, porém não altera a profundidade das glândulas sudoríparas.

Palavras-chave: Bos indicus, epitélio glandular, microscopia, histomorfometria, glândula sudorípara.

\section{INTRODUCTION}

Cattle are homoeothermic animals, therefore their body temperature is kept constant even under variations in environmental conditions because they are able to regulate the production and loss of heat. This ability in regulating body temperature may be affected by environmental factors and those related to the animal. Regarding the former, solar radiation, the number of animals per square meter and humidity, temperature and air velocity are some examples. As those related to the animals, genotype, age, physiological pattern, and others can be seen (Silva, 2000).

The cattle kept in warm environments display physiological alterations when trying to reach thermal balance. Peripheral vasodilation and the increase in heat dissipation by evaporation are both through the skin and by the increase in the respiratory frequency are examples of such alterations. Evaporation loss relies on the humidity and physiological factors, for example, activity and density of sweat glands. In cattle, body cooling by cutaneous evaporation is the most effective way to dissipate heat and thus, the sweat glands play an important role in this process, being paramount to the adaptation of ruminants to the tropical environment (Salimos, 1980).

The sweat glands, classified as apocrine, are the deepest layers of the skin and are associated with hair follicles. However, the eccrine type sweat glands are found in the nasolabial surface of cattle. Both are composed of an inner layer of polyhedral secreting cells and an outer layer of myofibrils (Silva, 2000).

Apocrine sweat glands open themselves exclusively in follicles and their secretory cells unload their product in the glandular lumen. Some of these cells rupture, releasing part of their cytoplasm. The cell nucleus remains intact to preserve the genetic material and to allow its reconstitution. To accomplish this reconstitution, the body spend extra energy expenditure, which is one of those responsible for the lower efficiency of the apocrine glands, in relation to eccrine glands of humans, in addition to presenting a discontinuous operation and intermittent outflow (Ferreira, 2005).

Nellore breed is known for hardiness and adaptability to the Brazilian climate and rearing conditions. Moreover, it presents breed ease, with regular calving and healthy calves. These factors contributed to make this breed the favourite among beef cattle farmers in Brazil. The mechanisms involved in its better tolerance to the tropical zone are attributed to the great heat dissipation capacity through the skin surface, the sweat glands in particular (Duarte et al., 2006).

The sweat glands may be related to the age of the animal, and therefore, they vary in their secretory capacity. Thus, the study of the effect of age on the histology of the sweat gland may help in understanding its development and give directions to a better management by age group in a tropical environment.

Thus, the objective of this work was to determine, by histomorphometry, the height of the glandular epithelium, the depth of the gland, the length of the glandular portion and the number of sweat glands per $\mathrm{cm}^{2}$ of three age groups of Nellore cattle, reared in Uberlandia, Minas Gerais.

\section{MATERIALAND METHODS}

The methodology of this study was approved by the Ethics Committee on the Use of Animals of the Federal University of Uberlândia, under the protocol 162/13.

The experiment used thirty female Nellore animals from a commercial herd in Uberlandia, Minas Gerais, Brazil (latitude 18 $53^{\circ} 23^{\prime \prime} \mathrm{S}$, longitude $48^{\circ} 17^{\prime} 19^{\prime \prime} \mathrm{W}$ and 865 meters above sea level), divided into three groups with 10 animals each: calves, heifers and cows, at 2 to 4 , 18 to 20 and 40 to 60 months of age, respectively.

Skin biopsy was performed in the summer, according to the technique described by Carter and Dowling, cited by Bianchini et al. (2006). Sampling was carried out by means of a minor surgery using a punch. The skin samples were collected $20 \mathrm{~cm}$ below the dorsolumbar line, in 
the middle third of the trunk. This region was previously shaved and antisepsis was performed with alcohol-iodoalcohol, and then local anaesthesia was applied by infiltration. After removal of the skin fragment, the perforation in the epidermis was stitched with a single surgical point. A healing anti-myiasis ointment was used daily in the stitched point.

The samples were fixed in $10 \%$ formalin for a minimum period of 48 hours. After that, they were taken to the Histology Laboratory of the Institute of Biomedical Sciences, Federal University of Uberlândia, dehydrated in ascending series of alcohol (70, 90 and $100 \%$ ), treated with xylol and infiltrated in liquid paraffin. Subsequently, they were transferred to another container with paraffin, whose solidification occurred at room temperature. The formed small blocks were cooled for ten minutes in order to become more consistent and to facilitate the microtomy.

Skin fragments of each animal was obtained by transversal incisions and serial sections ( $7 \mu \mathrm{m}$ thick) were performed in each block. Two cuts were placed on each blade. After that, they were deparaffinized and stained with hemotoxylin-eosin (Tolosa et al., 2003).

Histological sections were analyzed by scanned images, obtained in an Olympus Trinocular BX40 microscope, coupled to an Oly-200 camera, connected to a PC computer by a 3153 Data Translation plate scanner. The images were obtained with a microscope at objectives of 2x, 4x, 10x and 40x (Figures 1 and 2). The measurements were carried out by HL Image 97 program (Mastrantonio et al., 2002). The sweat glands were histomorphometrically evaluated by measuring the height of the glandular epithelium, the depth of the gland (distance from the bottom of the gland to the surface of the epithelium), length of the glandular portion and the number of sweat glands per $\mathrm{cm}^{2}$. This last parameter was obtained by counting the glands per $\mathrm{mm}$ and this value was squared and multiplied by 100 .

The Kolmogorov-Smirnov test was used to verify the data distribution behaviour was applied, where a normal distribution was found. The means of a total of 30 samples were evaluated by the " $t$ " test, with significance level of $5 \%$.

\section{RESULTS AND DISCUSSION}

Calves presented higher height of the glandular epithelium than heifers $(\mathrm{p}=0.0024)$, and cows $(\mathrm{P}=$ 0.0191 ) (Table 1). The difference obtained between calves and other categories indicates that as age increases, the secretory capacity of the gland becomes larger. This is due to the secretion of part of the cytoplasm of the cells of apocrine sweat gland while preserving the cell nucleus that will allow the reconstitution and therefore reduces the height of the glandular epithelium. Thus, the higher the secretory capacity, the lower the height of the epithelium (Ferreira, 2005).

Regarding the depth of the sweat gland, no difference was found among calves, heifers and cows ( $p>0.05)$ (Table 1), showing that this parameter does not change with age. However, the season in the year can influence it, with less depth in the summer because of the increase in the activity of the gland (Ferreira et al., 2009).

Cows have greater length of the secretory portion of the sweat gland than heifers $(\mathrm{p}=0.0379)$ and calves $(\mathrm{p}=$ 0.0077) (Table 1).

Heifers presented a higher number of sweat glands per $\mathrm{cm}^{2}$ skin than cows $(\mathrm{P}=0.023)$ (Table 1). Similar results were found by Mugale \& Bhosle (2002) in Deoni breed cattle. A reduction in the density of sweat glands from heifers to cows occurred because of the expansion
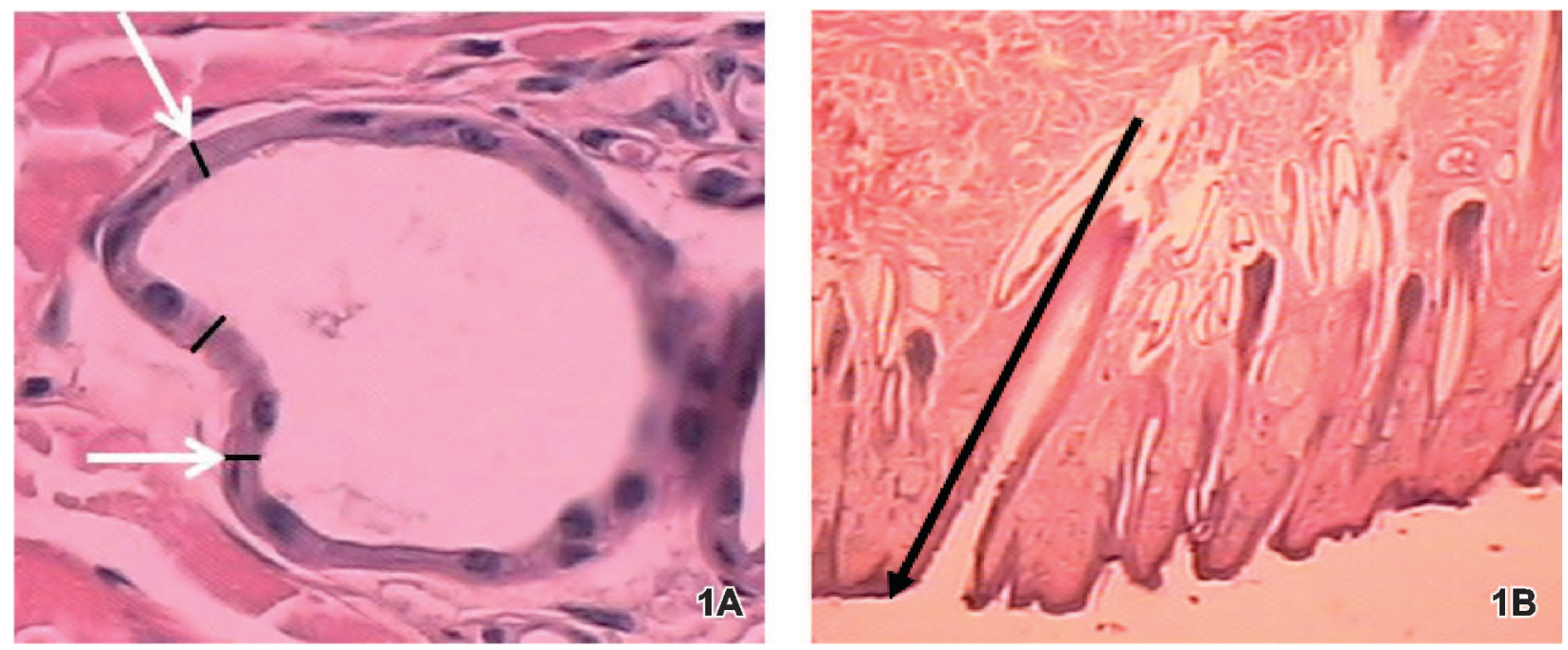

Figure 1. Photomicrography of the skin of Nellore cattle. 1A) epithelium of the sweat gland used to determine its height (white arrow) hemotoxylin-eosin (H\&E) stain 40x. 1B) to determine the depth of the sweat glands (black arrow) H\&E 10x. 

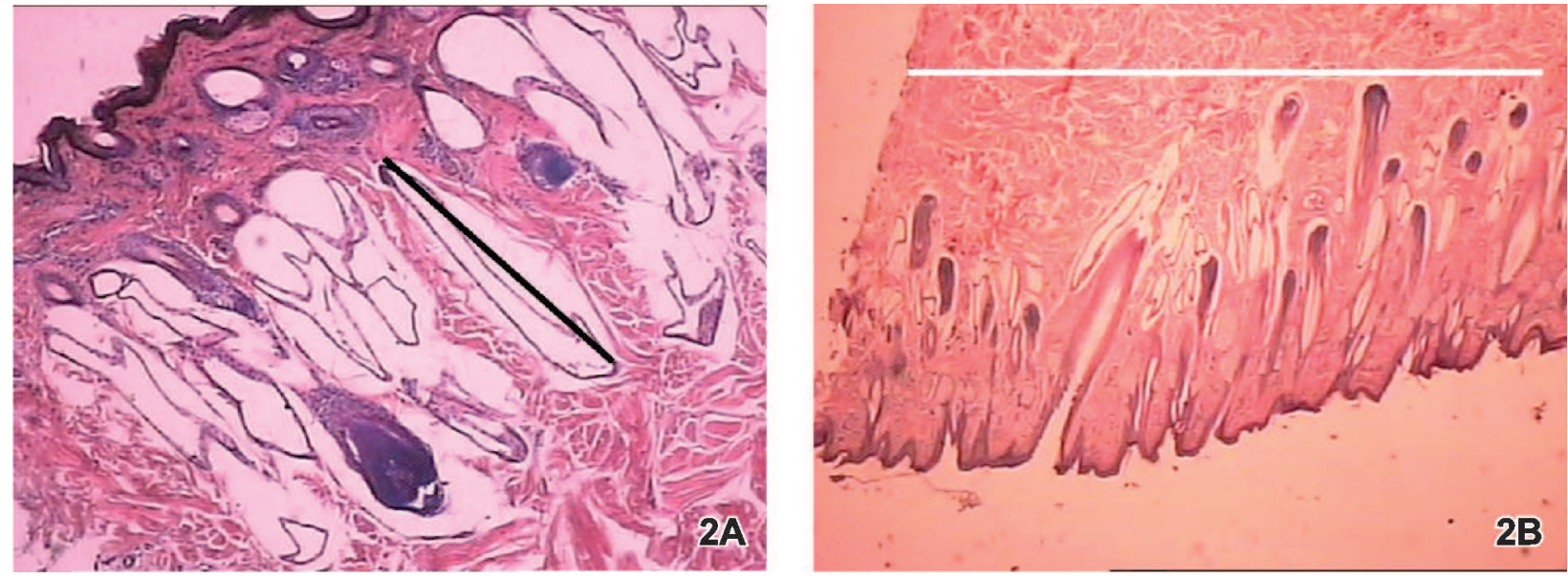

Figure 2. Photomicrography of the skin of Nellore cattle. 2A) Secretory portion of the sweat gland (black arrow) H\&E 10x. 2B) Sweat glands, white arrow as a reference to determine the density per $\mathrm{cm}^{2} \mathrm{H} \& \mathrm{E} 4 \mathrm{x}$.

Table 1. Mean and standard deviation of the epithelial height, depth and length of the glandular portion and density of sweat glands, in Nellore calves, heifers and cows.

\begin{tabular}{lcccc}
\hline & Height $(\boldsymbol{\mu m})$ & Depth $(\boldsymbol{\mu m})$ & $\begin{array}{c}\text { Length of the gland } \\
\text { portion }(\boldsymbol{\mu m})\end{array}$ & Number of glands $/ \mathbf{c m}^{2}$ \\
\hline Calves & $4.77 \pm 0.87 \mathrm{a}$ & $958.08 \pm 220.32 \mathrm{a}$ & $324.30 \pm 109.82 \mathrm{~b}$ & $3142.72 \pm 1914.96 \mathrm{ab}$ \\
Heifers & $3.53 \pm 0.70 \mathrm{~b}$ & $1029.64 \pm 177.42 \mathrm{a}$ & $344.20 \pm 112.48 \mathrm{~b}$ & $4018.29 \pm 1772.30 \mathrm{a}$ \\
Cows & $3.91 \pm 0.60 \mathrm{~b}$ & $1081.71 \pm 242.77 \mathrm{a}$ & $406.70 \pm 145.94 \mathrm{a}$ & $2666.68 \pm 1035.95 \mathrm{~b}$
\end{tabular}

Means followed by the same letters on the column do not differ from each other by the "t" test $(\mathrm{P}>0.05)$.

of the skin during growth and development of the animal as age advanced. In embryological development of the animal, all the hair follicles that it will have for all its life are formed. However, the apocrine glands are located parallel to hair follicles, therefore each hair follicle may represent a sweat gland (Banks, 1992). Thus, with the growth and development of the animal, those glands are redistributed in the skin.

The functionality of the sweat glands is paramount to achieve the thermal balance in cattle kept in high environment temperatures. Histology showed an increase in activity with age, showing higher sensitivity of adult animals to heat than the young ones. The increase in the glandular portion and the reduction in height of glandular epithelium are indicative of increased sweat production and better heat resistance.

\section{CONCLUSIONS}

As the animal get older, the epithelium height is reduced, the length of the secretory portion increases and the density per $\mathrm{cm}^{2}$ reduced; however, the depth of the sweat glands does not change.

\section{REFERENCES}

Banks WJ (1992) Histologia Veterinária aplicada. $2^{a}$ ed. São Paulo, Manole. 629p.
Bianchini E, Mcmanus C, Lucci CM, Fernandes MCB, Prescott E, Mariante AS \& Egito AA (2006) Características corporais associadas com a adaptação ao calor em bovinos naturalizados brasileiros. Pesquisa Agropecuária Brasileira, 41:1443-1448.

Duarte AB, Rezende JB, Nascimento MRBM \& Beletti ME (2006) Histomorfometria da glândula sudorípara de vacas nelores criadas em Uberlândia, MG. In: $4^{\circ}$ Congresso Brasileiro de Biometereologia, Ribeirão Preto. Anais, SBBIO. p.01-05.

Ferreira F, Campos WE, Carvalho AU, Pires MFA, Martinez ML, Silva MVGB, Verneque RS \& Silva PF (2009) Taxa de sudação e parâmetros histológicos de bovinos submetidos ao estresse calórico. Arquivo Brasileiro de Medicina Veterinária e Zootecnia, 61:763-768.

Ferreira RA (2005) Maior produção com melhor ambiente para aves, suínos e bovinos. Viçosa, Aprenda Fácil. 371p.

Mastrantonio EC, Eurípedes D, Beletti ME, Coelho CC, Shimizu BJ, Mota FCD \& Campos VA (2002) Morfometria das camadas da córnea de suínos da raça Large White. Arquivos de Ciências Veterinárias e Zoologia da UNIPAR, 5:79-83.

Mugale RR \& Bhosle NS (2002) Effect of age, sex and season on the sweat gland density and depth in deoni cattle. Indian Veterinary Journal, 79:157-159.

Salimos EP (1980) Alguns fatores que afetam a função sudorípara em vacas das raças Jersey e holandesa. Dissertação de Mestrado. Universidade Estadual Paulista "Júlio de Mesquita Filho", Jaboticabal. 44p.

Silva RG (2000) Introdução à bioclimatologia animal. São Paulo, Nobel. 286p.

Tolosa EMC, Rodrigues JR, Behmer AO \& Freitas Neto AG (2003) Manual de técnicas histológicas para histologia normal e patológica. $2^{\text {a }}$ ed. Barueri, Manole. 331p.

Rev. Ceres, Viçosa, v. 62, n.2, p. 129-132, mar-abr, 2015 